International Journal of Instruction e-ISSN: 1308-1470 • www.e-iji.net

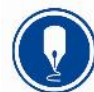

January $2022 \bullet$ Vol.15, No.1

p-ISSN: 1694-609X

pp. $219-236$

Article submission code:

20210210195341
Received: 10/02/2021

Revision: 17/06/2021
Accepted: 11/07/2021

OnlineFirst: 17/10/2021

\title{
The Effectiveness of a Training Program Based on Psychological Empowerment to Reduce Future Professional Anxiety among Students
}

\section{Fadi Soud Samawi}

Assoc. Prof., of Educational Psychology, Al-Balqa Applied University, Jordan, fadi.samawi@bau.edu.jo

\section{Sameer Abdelkareem Al Remawi}

Assoc. Prof., of Special Education, Al-Balqa Applied University, Jordan, sameer.remawi@bau.edu.jo

\section{Ahmed Abdel Halim Arabiyat}

Prof., of Psychological and Educational Counseling, Mu'tah University, Jordan, aarabiat55@yahoo.com

The study aimed to identify the effectiveness of a training program based on psychological empowerment to reduce future professional anxiety among outstanding students at Al-Balqa Applied University. The present study was a quasi-experimental research approach. The sample of the study consisted of (60) outstanding students who had high career anxiety, as they were distributed equally into two experimental (received a training program based on psychological empowerment) and control groups. To collect data, the study adopted professional future anxiety scale to measure future professional anxiety. The scale was ensured for validity and reliability by ensuring the facial and construct validity, in addition to using test-retest and Cronbach's Alpha equation methods to ensure the reliability. Descriptive statistics and independent samples ANCOVA were used to process the study data. The results indicated that there is an impact of the psychological empowerment program in favor of the experimental group in improving future professional anxiety. In conclusion, the study revealed the effectiveness of psychological empowerment program in reducing future professional anxiety among outstanding university students. The study recommends activating academic counseling by empowering the outstanding student psychologically to reduce his/her stress and anxiety, whether related to his current academic life or future career.

Keywords: psychological empowerment, future professional anxiety, outstanding students, training program, anxiety

Citation: Samawi, F. S., Al-Rimawi, S. A. K., \& Arabiyat, A. A. H. (2022). The effectiveness of a training program based on psychological empowerment to reduce future professional anxiety among students. International Journal of Instruction, 15(1), 219-236. https://doi.org/10.29333/iji.2022.15113a 


\section{INTRODUCTION}

The study is considered a new knowledge addition in psychotherapy based on psychological empowerment techniques. It links the psychological empowerment of the outstanding student with reducing their future professional anxiety and provides a survey of the literature related to psychological empowerment and future professional anxiety, especially in the aspect of available foreign studies and literature. The study also clarifies the future professional concern of the outstanding university student, especially that there is a shortage of Arab studies in general and local studies dealing with these variables.

Anxiety is generally an essential aspect of personality building and mental health as it may cause many diseases and psychological distress for the individual (Peker \& Ulu, 2018). The future is also a source of anxiety for the individual as everyone faces many doubts about it (Pittig et al., 2018). In university learning, many students face the problem of anxiety about the future (Al-Shannaq \& Leppavirta, 2020), especially professional anxiety because of the prevalence of unemployment, lack of jobs, and student's need to know their future destiny as the unemployment rate in Jordan, for example, reached 25\% by the end of 2019 (Majali, 2020). This applies to the outstanding university student, who suffers from future professional anxiety more than others because of his high expectations for his future career due to his excellence. There is no indication of the quality and profitability of this profession (Kapanadze, 2019).

Future professional anxiety is one of the most dangerous types of anxiety that afflicts students in general and outstanding students in particular (Trindade Júnior et al., 2021), and this is represented in fear of the unknown and expresses past and present experiences that they live, and their standing on the threshold of a new life and an ambiguous future, which they expect to match their mental capabilities and academic excellence (Al Hwayan, 2020).

Farley (2015) believes that outstanding university students possess mental, psychological, and social characteristics that differ from other students, and these characteristics in their entirety indicate academic and professional success. Farley (2015) pointed out that the expectations of those around them are often high that they will achieve professional success, as well as academic success. Thus they are subject to future professional anxiety due to their inability to realize their expected professional success or determine that they will succeed or not. This is consistent with what was indicated by Ozcan (2017) that excellent students add to the complexities of their advanced cognitive abilities; they fall under the pressures of the future, professionally and socially, as they feel that this future must be successful due to its association with these complexities, and the pressures surrounding them that require them to achieve great professional achievements, as well as the lack of any indicators indicating the quality of future professions, the methods of selecting it, and whether the student will achieve success in it.

According to Luoma (2018: 24), future professional anxiety means: "fear and tension resulting from the lack of clear perceptions about an individual's future career." According to Fatiha and Lummour (2019: 61), it was defined as "The negative response 
to fear, pressure, and uncertainty resulting from the inability to choose a future profession or the ambiguity of the student's options."

Several studies (Vigonli, 2015; Ozcan, 2017) have shown that students who are academically successful and who have high levels of intelligence plan to work in specific occupations that match their capabilities; because these abilities allow them to choose from among many professions, but this is not always in their interest, as the lack of adequate guidance for them, the ambiguity of the future professional role and the multiplicity of options put them in the problems of future professional anxiety (Belasco, 2013). This requires empowering them psychologically to be able to Professional selection, which reduces their future professional anxiety. Vignoli (2015) indicated that future professional anxiety negatively affects university students. It causes him to have psychological and academic maladjustment, lacking self-confidence, lack of responsibility, and low motivation for achievement. Twohig \& Levin (2017) also mentioned that future professional anxiety leads to a decline in the student's personal and academic motivation and leaves him prey to tension and psychological pressure, resulting in many psychological and organic disorders, the increase in negative and irrational thoughts, the inability to live with reality present and withdraw from facing future reality.

The role of psychological empowerment in reducing future professional anxiety among outstanding students is evident here, as it has a potential impact and expected results that benefit individuals. Psychological empowerment is also considered a means to encourage and increase the ability to make the right decision in situations that need this. Its effective role in enriching the experiences of the individual was praised for being a multi-dimensional motivating component. According to Spreitzers, it is an internal variable that allows the individual to feel and realizes that he has the power to get things done, based on specific dimensions that work interacting to increase the effectiveness of the individual, which appears on the individual's response to others and attitudes (Nikpour, 2018).

Psychological empowerment can also help reduce anxiety and improve efficiency, as they are forms of positive intervention that are concerned with increasing the individual's sense of joy and pleasure, satisfaction with various aspects of life, enhancing and maximizing capabilities (Al-Shannaq \& Leppavirta, 2020), and raising the morale directed towards improving the quality of life. Psychological empowerment is one of the broad concepts that accommodate many synonyms, meanings, and concepts such as empowerment, strengthening capacity, strengthening, attribution, and improving the situation (Singh \& Singh, 2019).

The researchers believe that the importance of psychological empowerment for outstanding students is evident in that it uses psychological interactions that highlight competence and confidence in the ability to perform tasks, a sense of the ability to influence work, freedom of choice in how to perform tasks, an understanding of the meaning of work, in addition to that, they can make current and future professional decisions clearly. Counseling and educational programs based on promoting psychological empowerment in young people help them develop specific psychosocial 
capabilities, such as competence, confidence, and self-efficacy, which are skills essential for future success. By participating in programs that allow adolescents to build their own definition of self, freely explore their life path, and implement their own change or future plans, teens gain a better understanding of their own identity. Group counseling programs, which aim to provide teens with a space for personal growth and support, can facilitate areas of growth related to self-identity, self-efficacy, and self-beliefs (Zimmerman, 2018).

In light of the importance of psychological empowerment and the problems caused by professional anxiety, many studies were conducted on students in general and outstanding students in particular. The study of Kong, Sun \& Yan (2016) in China aimed to reveal the effect of psychological empowerment in reducing future professional anxiety and improving future job satisfaction for a sample of (458) students from different disciplines and with various mental capabilities. The results showed a significant correlation between psychological empowerment and reducing future professional anxiety, and achieving future job satisfaction. The results indicated a need for academic and psychological university counseling programs that include the variables of psychological empowerment and future professional anxiety.

Ghanayem's study (2018) in Egypt examined the nature of the relationship between future professional anxiety and satisfaction with academic specialization and academic achievement on a sample of (136) male and female students from the Special Education Division. The study showed that there is a negative correlation between future professional anxiety and both satisfaction with academic specialization and academic achievement, and future anxiety does not constitute a significant effect in predicting academic achievement. The study of Mukhaimer and Al-Wathenani (2018) in the Kingdom of Saudi Arabia, which was conducted on (300) students of Umm Al-Qura University, indicated that the level of future professional anxiety among students is high and that there is a need for mentoring programs to reduce the level of this anxiety. Sayed (2019) conducted a study in Egypt to discover the effectiveness of acceptance and commitment therapy in reducing future anxiety among special education students. The study results on a sample of (9) students showed the program's effectiveness based on acceptance and commitment therapy in reducing students' future anxiety.

As for Al-Majali's study (2019), it was conducted on a sample of (30) university students from the ordinary and superior to raise the level of their professional competence and reduce their future anxiety. The results showed that cognitive, emotional, psychological, mental, and behavioral techniques significantly reduce the level of future anxietyand increase the efficiency of the student, whether the student is excellent or ordinary. Also, the Dahmisheh study (2019), which was conducted on a sample of 592 male and female students, showed that psychological empowerment reduces students' anxiety, increases their academic efficiency, and increases their motivation for achievement. Also, Azizi, Heiderzadi, Soeouh, Jantaolmahkhan \& Khatony, 2020 conducted a study in Iran that explored the relationship between psychological empowerment, self-affirmation anxiety reduction among students of the College of Nursing in Tehran. The study sample consisted of (200) female students who answered the scale of psychological empowerment and self-affirmation. It was found 
that there is an effective effect of psychological empowerment in increasing the student's ability to persevere, improving self-confidence, and the profession in which she will work in the future. Through the studies that have been presented, it is noticed that psychological empowerment has a significant effect in reducing future anxiety, but it is noticed that most of the studies followed relational descriptive methodologies and dealt with university student samples without specifying the characteristics of the students. The studies did not address the study sample of outstanding students in an experimental study. Accordingly, the current research is distinguished by its approach to an effective program based on psychological empowerment to reduce future professional anxiety among outstanding students at Al-Balqa Applied University, especially in the absence of local studies - as far as researchers are aware - that combined these two variables.

Career future anxiety is at the top of the list of future anxiety among university students, especially the outstanding ones. This leaves negative effects on the university student in two crucial aspects: the psychological and academic elements. These findings are consistent with the results of many studies that have dealt with the subject, as the Yousef et al (2018) study showed that the Jordanian university student suffers from future professional anxiety. The study of Pulliam \& Gonzalez (2018) in the United States of America showed that high-achieving students in public universities could not determine their professional future, which puts them in the circle of fear and tension. Sayed's study (2019) also indicated a high level of future professional anxiety among the Faculty of Special Education students in Egypt.

The severity of future professional anxiety is more pronounced among outstanding students than among other students because they are quick to excite more than others (Muhammad, 2010). This might be attributed to that their high mental traits and high achievement, they feel the need to find outstanding work in the future (Sayed, 2019), which increases their future professional anxiety level. Through the work of researchers in university teaching, especially in the field of educational psychology, talent and excellence, they noticed that the level of anxiety and tension associated with the future profession is high among excellent students more than others; this causes them many psychological, academic and social problems. This calls for the need to improve their mental health and empower them psychologically by giving meaning to their work and increasing their perseverance and persistence. Therefore, the researchers decided to conduct this study to reveal the effect of a program based on psychological empowerment in reducing future professional anxiety among outstanding students at AlBalqa Applied University. The current study tried to test the following hypothesis:

There were no statistically significant differences $(\alpha=0.05)$ between the mean scores of the treatment group based on psychological empowerment and the control group on the scale of future professional anxiety among the outstanding students at Al-Balqa Applied University / Center.

\section{The Purpose of the Study}

The purpose of the present study was to reveal the effectiveness of a training program based on psychological empowerment to reduce future professional anxiety among outstanding students at Al-Balqa Applied University. 


\section{Procedural Definitions of Terms}

Psychological Empowerment: Dedoni and Bergo (2020: 48) defined it as "the intrinsic internal stimulus that emerges through several perceptions (meaning, competence, choice, and influence) that reflect individuals' attitudes towards the tasks they perform and the assignments; assigned to them." It is procedurally defined as a set of intervention strategies provided within an integrated program to reduce future professional anxiety among outstanding students at Al-Balqa Applied University.

Career future anxiety: Bisson (2017: 22) defined it as "the feeling that afflicts the student with anxiety, fear, and lack of reassurance due to his negative perceptions and attitudes towards obtaining a career in the future and the fear of not achieving material and moral returns from this profession. " Procedurally, it is defined as the degree that the respondent obtains on the scale of future professional anxiety, which is composed of the following dimensions (negative thinking in the future, thinking about the study and prospects for specialization, the possibility of obtaining the profession and its importance, achieving family and social stability used in the current study.

Outstanding Students: Bin Al-Abyad and Belmokhtar (2019: 299) defined it as "a student who is distinguished by high academic achievement in the fields of humanities, social sciences, natural sciences, and mathematics, and he is distinguished by mental abilities with certain personality traits related to high academic achievement and the possession of creative thinking skills." Procedurally, they are defined as Students with high academic achievement and from various colleges and specialties at the Bachelor's level, whose cumulative GPA is not less than 3.65 .

\section{METHOD}

\section{Research design}

The study adopted the quasi-experimental research approach, which involves the recruitment of a study sample and dividing the participants into a control group and an experimental group. Quasi-experiments are generally used to demonstrate the causal relationship.

\section{The population of the Study}

The study population consists of all the outstanding students at Al-Balqa Applied University / Center and who have a GPA of (3.65) and above, whose number is (416) students, according to the statistics of the Admission and Registration Unit. Outstanding students were chosen as they are the most promising category of university students that need to be monitored and empowered in order to prepare future leaders in the community.

\section{Sample of the Study}

The purposive sampling procedure was used to recruit the study participants. The professional Future Anxiety Scale was applied to all outstanding students. After analyzing the results, those who achieved the highest score on the Future Professional Anxiety Scale were selected, and their number reached (65) students. After consulting with the students, (60) students agreed to participate in the program, and they were distributed equally into two experimental and control groups. 


\section{Study Tool}

First: Occupational Future Anxiety Scale:

A scale developed by Ahmad and Salmi (2015) was used, and the scale consisted of (38) items, distributed on the following dimensions. Table (1) shows the scale domains ad the representing items.

Table 1

The domains and the items' distribution of the Occupational Future Anxiety Scale

\begin{tabular}{lll}
\hline Dimension & No. of items & items \\
\hline Negative thinking about the future & 8 & $1,5,9,13,17,21,25,29$ \\
\hline $\begin{array}{l}\text { Reflection on study and prospects for } \\
\text { specialization }\end{array}$ & 9 & $2,6,10,14,18,22,26,30,33$ \\
\hline $\begin{array}{l}\text { The possibility of obtaining a } \\
\text { profession and its importance }\end{array}$ & 13 & $\begin{array}{l}3,7,11,15,19,23,27,31,34,35, \\
36,37,38\end{array}$ \\
\hline Achieving family and social stability & 8 & $4,8,12,16,20,24,28,32$ \\
\hline Overall scale & 38 & 38 \\
\hline
\end{tabular}

The two researchers extracted the scale validity coefficients through the arbitrators' veracity, amending the paragraphs and controlling them by applying the Lauchy equation to calculate the arbitrators' degree of agreement. The study extracted the discriminatory validity through a pilot sample that consists of (30) university students in Algeria, where the calculated value of (t) was (16.72), which is greater than the tabulated $(t)$, which indicates the validity of the scale. The self-validity was also extracted by calculating the square root coefficient of the test reliability coefficient, where the self-validity reached $(0.91)$, while the stability of the half segmentation was done through the Pearson correlation coefficient, which reached (0.90), which indicates the validity of the scale for application. The answer to the scale is done by placing a sign in the box that expresses the student's answer according to the alternatives presented, and the correction key included (agree - 3 degrees), (neutral - 2 degrees), (disagree - one score), through the number of future occupational anxiety levels to three levels, low (38$63)$, i.e., from (1-1.66), medium (64-89), i.e., from (1.67-2.33), and high (90-114), i.e., from (2.34-3) ) As the length of the class is 25 .

\section{Indicators of construct validity for the scale used in the current study}

The validity of the arbitrators

The scale was presented to (4) arbitrators specialized in educational and counseling psychology. They were asked to express their views on the scale's validity to measure university students' future professional anxiety, the paragraph's clarity, and its belonging to the field. The arbitrators agreed on all the items of the scale with some simple language adjustments.

\section{Internal consistency validity}

The items' correlation coefficients were extracted on the overall scale and in the dimension to which they belong to extract the indications of the validity of the scale's internal consistency on (25) superior students from outside the study sample. The items' correlation coefficients with the tool as a whole ranged between $(0.351-0.765)$, and 
with the dimension to which it belongs, between (0.356-0.730), and Table (2) shows that:

Table 2

Correlation coefficients between the paragraphs, the dimension to which they belong, and the total score on the study scale

\begin{tabular}{|c|c|c|c|c|c|c|c|c|}
\hline $\begin{array}{l}\text { Item } \\
\mathrm{N} .\end{array}$ & $\begin{array}{l}\text { Correlation } \\
\text { to the tool }\end{array}$ & $\begin{array}{l}\text { Correlation to } \\
\text { the dimension }\end{array}$ & $\begin{array}{l}\text { Item } \\
\mathrm{N} .\end{array}$ & $\begin{array}{l}\text { Correlation } \\
\text { to the tool }\end{array}$ & $\begin{array}{l}\text { Correlation } \\
\text { to the } \\
\text { dimension }\end{array}$ & $\begin{array}{l}\text { Item } \\
\text { N. }\end{array}$ & $\begin{array}{l}\text { Correlatio } \\
\mathrm{n} \text { to the } \\
\text { tool }\end{array}$ & $\begin{array}{l}\text { Correlation to } \\
\text { the dimension }\end{array}$ \\
\hline 1. & $.502 * *$ & $.524 * *$ & & $.419^{*}$ & $.715^{* *}$ & 27. & $.424 *$ & $.723 * *$ \\
\hline 2. & $.420 *$ & $.534 * *$ & & $.765^{* * *}$ & $.375^{*}$ & 28. & $.367 *$ & $.603 * *$ \\
\hline 3. & $.368 *$ & $.700^{* * *}$ & & $.612^{* *}$ & $.439 * *$ & 29. & $.672 * *$ & $.454 * *$ \\
\hline 4. & $.420 * *$ & $.513^{* *}$ & & $.533^{* * *}$ & $.734 * *$ & 30. & $.382^{*}$ & .439 ** \\
\hline 5. & $.530 * *$ & $.530^{* *}$ & & $.521^{* *}$ & $.612^{* * *}$ & 31. & $.510^{* *}$ & $.521 * *$ \\
\hline 6. & $.513 * *$ & $.513^{* * *}$ & & $.630^{* * *}$ & $.530 * *$ & 32. & $.442 *$ & $.630 * *$ \\
\hline 7. & $.354 *$ & $.726^{* *}$ & & $.419^{*}$ & $.593 * *$ & 33. & $.351 *$ & $.555 * *$ \\
\hline 8. & $.486 * *$ & $.371 *$ & & $.441^{*}$ & $.530^{* * *}$ & 34. & .499 ** & $.513 * *$ \\
\hline 9. & $.550 * *$ & $.622^{* *}$ & & $.384^{*}$ & $.395^{*}$ & 35. & $.433^{*}$ & $.530 * *$ \\
\hline 10. & $.621 * *$ & $.356^{*}$ & & $.593^{* *}$ & $.393^{*}$ & 36. & $.455^{*}$ & $.513 * *$ \\
\hline 11. & $.502 * *$ & $.524 * *$ & & $.419 *$ & $.705^{* *}$ & 37. & $.367 *$ & $.603 * *$ \\
\hline 12. & $.420 *$ & $.534 * *$ & & $.760^{* *}$ & $.376^{*}$ & 38. & .679 ** & $.454 * *$ \\
\hline 13. & $.364 *$ & $.730^{* * *}$ & & $.612^{* *}$ & $.439^{* *}$ & & & \\
\hline
\end{tabular}

* Statistically significant at the significance level (0.05).

** Statistically significant at the significance level (0.01).

It is evident from Table (2) that the items' correlation coefficients with the total score for both dimensions to which they belong were statistically significant at the significance levels $\alpha=0(0.05)$ and (0.01). Therefore, none of them were omitted, which indicates that the scale is suitable for measuring the level of future professional anxiety among the study sample, and this shows that the scale has high validity and is appropriate for the current study.

\section{The Reliability of the Scale}

The reliability coefficient was used by the internal consistency method according to the Cronbach-alpha equation and the instrument's return constancy to check the reliability. Where the coefficient of total internal consistency of the Cronbach Alpha method was (0.79), whereas it reached (0.81) using test/retest, and Table (3) shows that.

Table 3

Coefficients for the reliability of the measure of future professional anxiety using test/retest and Cronbach alpha methods

\begin{tabular}{lll}
\hline Dimension & Test/retest reliability & Cronbach Alpha \\
\hline Negative thinking about the future & 0.83 & 0.80 \\
\hline Reflection on study and prospects for specialization & 0.81 & 0.79 \\
\hline The possibility of obtaining a profession and its importance & 0.80 & 0.78 \\
\hline Achieving family and social stability & 0.82 & 0.77 \\
\hline Overall scale & 0.81 & 0.79 \\
\hline
\end{tabular}

Based on the results shown in table (3), it can be observed that the professional future anxiety scale obtained a high-reliability score, which means that it could be administered on the original study sample. 
The training program: It is based on the psychological empowerment literature, a program was developed consisting of (9) sessions, each session lasting 45 minutes, and the following is a presentation of the program sessions:

The first session (introduction and acquaintance): included providing room for acquaintance between the participating students and the mentor, introducing the program, its objectives, and what could be achieved through it, and holding a group of meetings to discuss among the participating students, and clarifying and discussing the concept of psychological empowerment.

The second session (Future professional anxiety, its definition, causes, forms, and effects) included giving a clear and comprehensive conception of the concept in general and identifying its causes and forms, and the identification of its implications, and a discussion of the psychological, physical, social and mental impacts of it.

The third session (training on learning to tolerate stress): Included changing ideas about the concept of reaching idealism and perfection and talking about the tensions in the lives of group members.

The fourth session (theater acting): This included helping students express their thoughts and feelings freely, developing their skills and abilities to express and act in difficult situations, and providing them with a store of knowledge and practical experiences to deal with difficult situations.

Fifth session (role-swapping): It includes automaticity in representation and improvisation in expression. It is considered a recreational activity in which students 'cognitive, emotional, and psychomotor experiences and skills are developed according to an organized plan.

The sixth session (entertainment games, fun, and entertainment) is a way of fun and the link between the integrity of the mind and the health of the body. In addition, it included competition between members of the group.

The seventh session (training in the relaxation method): It included relieving stress and anxiety, and explaining the importance of the skill of relaxation in general for the individual in getting rid of the problems and pressures they suffer from, and clarify the necessary conditions for the skill of relaxation, and improve future professional anxiety in the minds of group members, especially in difficult situations.

The eighth session (problem-solving skills): Included identifying problem-solving skills and their importance, to identify problems, goals and alternatives, their balance, and decision-making.

The ninth session (ending and evaluating the counseling program): Which included discussion of the group members about the pros and cons of the program, knowing the improvement that the group members feel after completing the sessions, standing on the strengths and weaknesses, and thanking the group participating in the program.

\section{Study Procedures}

The study procedures included reviewing the educational literature on the subject of the study and previous studies that dealt with counseling programs, especially the programs 
directed to outstanding students, and then applying the scale of future professional anxiety to the two groups; and after that, the counseling program was applied to the experimental group at the rate of two sessions per week, the duration of each session (45) minutes.

\section{Homogeneity of Groups}

To verify the groups' homogeneity, the means and standard deviations of the students' performance were extracted on the scale of future professional anxiety according to the group variable (experimental, control). The "T" test was used to clarify the statistical differences between the arithmetic means, and Table (4) illustrates that. The scale was distributed on the students in both groups (control and experimental) before implementing the training program on the experimental group. based on the responses of the participating students, the researchers calculated the means and standard deviations for each of the scale domains.

Table 4

Means and standard deviations of students' performance on the scale of pre-future professional anxiety according to the group variable (experimental, control)

\begin{tabular}{|c|c|c|c|c|c|c|}
\hline Dimension & Group & Mean & $\begin{array}{l}\text { standard } \\
\text { deviation }\end{array}$ & $\mathrm{N}$ & $\begin{array}{l}\mathrm{T} \\
\text { value }\end{array}$ & Sig \\
\hline \multirow[t]{2}{*}{ Negative thinking about the future pretest } & Experimental & 2.45 & .374 & 30 & \multirow[t]{2}{*}{.517} & \multirow[t]{2}{*}{.611} \\
\hline & Control & 2.37 & .415 & 30 & & \\
\hline \multirow{2}{*}{$\begin{array}{l}\text { Reflection on study and prospects for } \\
\text { specialization pretest }\end{array}$} & Experimental & 2.57 & .478 & 30 & \multirow[t]{2}{*}{.862} & \multirow[t]{2}{*}{.398} \\
\hline & Control & 2.36 & .469 & 30 & & \\
\hline \multirow{2}{*}{$\begin{array}{l}\text { The possibility of obtaining a profession } \\
\text { and its importance pretest }\end{array}$} & Experimental & 2.38 & .378 & 30 & \multirow[t]{2}{*}{.339} & \multirow[t]{2}{*}{.103} \\
\hline & Control & 2.35 & .338 & 30 & & \\
\hline \multirow{2}{*}{$\begin{array}{l}\text { Achieving family and social stability } \\
\text { pretest }\end{array}$} & Experimental & 2.40 & .452 & 30 & \multirow[t]{2}{*}{1.725} & \multirow[t]{2}{*}{.738} \\
\hline & Control & 2.34 & .554 & 30 & & \\
\hline \multirow[t]{2}{*}{ Total Professional future concern pretest } & Experimental & 2.43 & .416 & 30 & \multirow[t]{2}{*}{1.162} & \multirow[t]{2}{*}{.198} \\
\hline & Control & 2.36 & .492 & 30 & & \\
\hline
\end{tabular}

It is evident from Table (4) that there are no statistically significant differences at the level of significance (0.05) attributable to the group in all sub-dimensions and the overall score of the scale of future professional anxiety pretest, and this result indicates the equality of the groups.

\section{Data Processing}

The researcher's processed the data statistically through the Statistical Package of Social Sciences (SPSS, v. 25, IBM corporation). First, the researchers ensured the normality of the data using the Kolmogorov-Smirnov Test. The Cronbach's Alpha equation and Pearson correlation coefficient were used to assess the reliability of the study scale. In addition, the researchers ensured the homogeneity of the study groups. Moreover, descriptive statistics and Analysis of Covariance (ANCOVA) were determined as the appropriate statistical tests to test the study hypothesis.

\section{FINDINGS}

The results shown in Table (5) represent the demographic characteristics of the study participants. The results showed that there was almost equal representation of males and 
females among the study groups as males constituted $46.7 \%(n=14)$ and $43.3 \%(n=13)$ of the control and experimental groups, respectively. In addition, females constituted $53.3 \%(n=16)$ of the control group, whereas they constituted $56.7 \%(n=17)$ of the experimental group.

Distributing the study participants based on the academic level revealed that first-year students were $6.7 \%(n=2)$ of the total control group and $10 \%(n=3)$ of the total experimental group. In addition, the second-year students constituted $20 \%(n=6)$ and $23.3 \%(n=7)$ of the control and experimental groups, respectively. The third-year students were constituting $26.7 \%(n=8)$ of the total control group and $30 \%(n=9)$ of the experimental group. Finally, the fourth-year students constituted $46.7 \%(n=14)$ of the control group members and $11 \%(\mathrm{n}=11)$ of the experimental group.

Table 5

Demographic characteristics of the study participants in the control group and the experimental group

\begin{tabular}{lll}
\hline Variable & Control group $(\mathrm{N}=30)$ & Experimental $(\mathrm{N}=30)$ \\
\hline Gender & $\mathrm{N}(\%)$ & $\mathrm{N}(\%)$ \\
1. Male & $14(46.7 \%)$ & $13(43.3 \%)$ \\
2. Female & $16(53.3 \%)$ & $17(56.7 \%)$ \\
\hline Academic level & & \\
1. First & $2(6.7 \%)$ & $3(10 \%($ \\
2. Second & $6(20 \%)$ & $7(23.3 \%)$ \\
3. Third & $8(26.7 \%)$ & $9(30 \%)$ \\
4. Fourth or more & $14(46.7 \%)$ & $11(11 \%)$ \\
\hline
\end{tabular}

The main hypothesis: There are no statistically significant differences $(\alpha=0.05)$ between the mean scores of the treatment group based on psychological empowerment and the control group on the scale of future professional anxiety among outstanding students at Al-Balqa Applied University.

To test the main study hypothesis, the researchers calculated the mean scores and standard deviations of the participants' responses on the future professional anxiety scale. The mean scores and standard deviations were extracted to estimate the level of future anxiety in the study sample, and Table (6) illustrates this.

Table 6

Means and standard deviations for the dimensions of future professional anxiety

\begin{tabular}{clrcc}
\hline Item N. & Rank & Dimension & Mean & $\begin{array}{l}\text { standard } \\
\text { deviation }\end{array}$ \\
\hline 4 & Negative thinking about the future & 2.35 & .630 & High \\
\hline 1 & Reflection on study and prospects for specialization & 2.44 & .582 & High \\
\hline 3 & The possibility of obtaining a profession and its importance & 2.36 & .619 & High \\
\hline 2 & Achieving family and social stability & 2.41 & .527 & High \\
\hline Total Professional future Anxiety & 2.39 & .616 & \\
\hline
\end{tabular}

Table (6) shows that the mean scores of future career dimensions ranged between $(2.35$ 2.44) and high. Where, after considering the study and prospects for specialization, it came first with the highest arithmetic average of (2.44), and in the last place after 
negative thinking in the future, with an arithmetic mean of (2.25), and the total arithmetic mean of future professional anxiety of (2.39) with a high level.

Table 7

Means and standard deviations of the control and experimental groups on the pre and post measurement of the Occupational Future Anxiety Scale

\begin{tabular}{lllll}
\hline \multirow{2}{*}{ Group } & Mean & \multicolumn{3}{c}{ Standard deviation } \\
\cline { 2 - 5 } & Pre & Post & Pre & Post \\
\hline Experimental & 44.172 & 39.575 & 8.492 & 5.061 \\
\hline Control & 46.820 & 49.748 & 5.356 & 3.483 \\
\hline
\end{tabular}

It is evident from Table (7) that the average of the experimental group is $(39,575)$, and that the average of the control group is $(49,748)$, and to verify that the direction of the difference between the averages of the scale of occupational anxiety scale if they are statistically significant, an analysis of covariance (ANCOVA) was used and Table (8) illustrates the results of covariance analysis.

Table 8

Results of the Co-variance analysis of the differences between the averages of the experimental and control groups for the scale of future professional anxiety for the total degree

\begin{tabular}{llllll}
\hline Source of variance & Sum of squares & Degrees of freedom & Mean of squares & P & Sig \\
\hline Pre- Measurement & 7.934 & 1 & 7,934 & 0.378 & 0.545 \\
\hline Groups & 634.17 & 1 & 634.17 & 30.024 & $0.000^{*}$ \\
\hline Error & 52.14 & 57 & 2.075 & & \\
\hline Total & 718.70 & 59 & & & \\
\hline
\end{tabular}

It is evident from Table (8) that the differences between the averages reached the level of statistical significance, as the statistical $(\mathrm{P})$ value reached (30.024), which is a statistical function at a level less than (0.05). By reference to the Table of arithmetic averages, we note that the differences favored students who received a program based on psychological empowerment, as their level of future professional anxiety decreased significantly. To examine this hypothesis, the arithmetic averages and standard deviations were calculated for each of the members of the experimental group and the control group, as Table (9) shows the arithmetic averages and standard deviations of the scale of future professional anxiety on the dimensions on the pre and post measurement.

Table 9

Means and standard deviations of the control and experimental groups on the pre and post measurement of the dimensions of future professional anxiety

\begin{tabular}{llllll}
\hline Dimensions & Group & Mean & \multicolumn{2}{c}{ Standard deviation } \\
& & Pre & Post & Pre & Post \\
\hline Negative thinking about the future & Experimental & 12.134 & 6.401 & 2.476 & 1.869 \\
& Control & 11.932 & 13.602 & 1.334 & 1.458 \\
\hline Reflection on study and prospects for & Experimental & 16.000 & 9.872 & 2.803 & 2.657 \\
specialization & Control & 18.266 & 13.805 & 2.261 & 1.902 \\
\hline The possibility of obtaining a profession and & Experimental & 14.600 & 6.865 & 2.971 & 2.231 \\
\cline { 2 - 6 } its importance & Control & 16.732 & 16.032 & 3.172 & 2.4051 \\
\hline Achieving family and social stability & Experimental & 17.401 & 8.401 & 4.064 & 3.019 \\
\cline { 2 - 6 } & Control & 18.936 & 19.613 & 2.681 & 2.584 \\
\hline
\end{tabular}


It is evident from Table (9) that the average members of the experimental group for the dimension of negative thinking in the future reached (6.401), and that the average of the members of the control group was (13.602), and the average of the members of the experimental group for the dimension of thinking in the study and prospects for specialization was (9.872), and that the average of the control group members is $(13,805)$, the average of the experimental group members for the dimension of obtaining a profession and its importance is $(6,865)$, and that the average of the control group members is $(16,032)$, and that the average of the control group members was $(13,805)$, the average of the experimental group members for the dimension of achieving family and social stability was (8.401), and that the average of the control group members was $(19,613)$, and to verify that the difference between the averages for the dimensions of occupational anxiety, if they are statistically significant, an analysis of common variance (ANCOVA) was used. Table (10) shows the results of the analysis of covariance.

Table 10

Results of the co-variance analysis of the differences between the averages of the experimental and control groups for the dimensions of the future professional anxiety scale

\begin{tabular}{llllllr}
\hline Dimensions & $\begin{array}{l}\text { Source of } \\
\text { variance }\end{array}$ & $\begin{array}{l}\text { Sum of } \\
\text { squares }\end{array}$ & $\begin{array}{l}\text { Degrees of } \\
\text { freedom }\end{array}$ & $\begin{array}{l}\text { Mean of } \\
\text { squares }\end{array}$ & P & Sig \\
\hline $\begin{array}{l}\text { Negative thinking about the } \\
\text { future }\end{array}$ & $\begin{array}{l}\text { Pre- } \\
\text { measurement }\end{array}$ & 148.083 & 1 & 148.083 & 13.805 & $0.000^{*}$ \\
\hline $\begin{array}{l}\text { Reflection on study and } \\
\text { prospects for specialization }\end{array}$ & $\begin{array}{l}\text { Pre- } \\
\text { measurement }\end{array}$ & 380.037 & 1 & 680.03 & 30.032 & $0.000^{*}$ \\
\hline $\begin{array}{l}\text { The possibility of obtaining a } \\
\text { profession and its importance }\end{array}$ & $\begin{array}{l}\text { Pre- } \\
\text { measurement }\end{array}$ & 298.532 & 1 & 298.532 & 22.655 & $0.000^{*}$ \\
\hline $\begin{array}{l}\text { Achieving family and social } \\
\text { stability }\end{array}$ & $\begin{array}{l}\text { Pre- } \\
\text { measurement }\end{array}$ & 357.162 & 1 & 357.162 & 27.427 & $0.000^{*}$ \\
\hline
\end{tabular}

It is evident from Table (10) that the differences between the averages for the dimensions of the Occupational Future Anxiety Scale were statistically significant at a level less than (0.05). Concerning the Table of arithmetic averages, we note that the differences were in favor of students who received a program based on psychological empowerment, as their level of future professional anxiety decreased for the four dimensions in a statistically significant way.

\section{DISCUSSION}

The present study aimed at investigating the effectiveness of a training program based on psychological empowerment to reduce future professional anxiety among outstanding students at Al-Balqa University. The results of the study showed that the future career domain was scored highest, whereas negative thinking in the future was scored lowest. This result appears to be justified. The concern of the outstanding students caused by their professional anxiety is justified in light of the increase in the number of graduates, the lack of job opportunities, the exacerbation of unemployment, and the overcrowding of specializations. Job opportunities are not related to excellence as much as they are related to the needs of the labor market or the Civil Service Bureau's requirements, 
which increases their anxiety, especially as they seek after graduation to work in a way that achieves family and social stability.

In this context, Al Hwayan (2020) believes that future professional anxiety represents one of the most dangerous types of anxiety that afflicts students in general, and outstanding students in particular, as this is illustrated in the fear of an unknown that denotes past and present experiences that they live, and their standing on the threshold of a new life and an uncertain future, which they expect from it to match their mental capabilities, and academic superiority, and this is consistent with what was indicated by Ozcan (2017) that excellent students add to the complexities of their advanced cognitive abilities; they fall under future pressures, professionally and socially, as they feel that this future must be successful due to its association with these complexities, and its connection to the pressures surrounding them, which require them to achieve great professional achievements, and also, because there are no indicators that indicate the quality of future professions, the methods of selecting them, and whether the student will achieve success in them. The results of the study were in agreement with the studies of Ghanayem (2018), Mukhaimer and Al-Wutainani (2018), and Sayed (2019), which showed an increase in the level of anxiety for the future career of students. The arithmetic means and standard deviations were calculated for each experimental and control group to examine this hypothesis. Table (5) shows the arithmetic averages and standard deviations of future professional anxiety scale on the pre and postmeasurement.

In addition, the results showed that there was a significant statistical difference between the mean scores of the experimental and control groups for the scale of future professional anxiety for the total degree. The study found that this difference was in favor of the experimental students who received a program based on psychological empowerment, as their level of future professional anxiety decreased significantly.

The results showed that the level of future professional anxiety among students of the experimental group is low compared to their counterparts in the control group, and the researchers attribute this result to the fact that the program applied in the study, including its procedures and practical activities, enables to increase the rates of satisfaction and motivation of students who are excelling in their specializations and their future academic and professional status, the program also increased students' awareness of the attributes and skills they possess that enable them to face future professional pressures, in addition to providing them with the ability to self-control and control the circumstances surrounding them, and this, in turn, increased their psychological empowerment and reduced their future professional anxiety.

Nikpour (2018) believes that psychological empowerment contributes significantly to lowering future professional anxiety among outstanding students, as it has a potential impact and expected results that benefit individuals. Psychological empowerment is a means to encourage and increase the ability to make the right decision in situations that need this. Nikpour (2018) also cited its effective role in enriching the individual's experiences for being a multi-dimensional motivating component, and psychological empowerment allows the individual to feel and realize that he can accomplish tasks 
based on specific dimensions that work interacting to increase the effectiveness of the individual, which appears on the individual's response to others and situations.

This result is in agreement with the results of the study of Sayed (2019), Al-Dahamsheh (2019), and the study of Azizi, Heiderzadi, Soeouh, Jantaolmahkhan \& Khatony, 2020) that there is a significant effect of psychological empowerment in increasing the student's ability to persevere, improve self-confidence, and the profession in which she will work in the future.

\section{CONCLUSION}

The present study sought to investigate the effectiveness of a training program based on psychological empowerment on reducing future professional anxiety among outstanding students. The findings of the study showed that a well-structured and designed training program based on the inclusion of various psychological empowerment significantly reduced the future professional anxiety among outstanding undergraduates at Al-Balqa Applied University. The set of activities and tasks included in the training program, such as role-play, gamification activities, relaxation activities, etc., significantly improved the communication, interaction, and socialization of the students and reduced the negative thoughts of the students about the future. The practical implications of this research involve the benefits of using the tasks and activities to design psychological empowerment programs targeting the outstanding university students in general and all undergraduates in particular. In addition, the research implication of this study involves that this study might be extended to include different categories of university students and different psychological empowerment activities.

\section{LIMITATIONS}

Study limits: The current study was limited to outstanding students in various academic years at Al-Balqa Applied University for the first semester of the academic year 2019/2020.

Study limitations: The generalization of the results of the study is determined by the psychometric properties of the scales used, the extent to which the study sample is serious about adhering to the training program, and their seriousness in answering the scale.

\section{SUGGESTION AND RECOMMENDATIONS}

The study results may benefit educational counselors and psychologists by providing an effective counseling program based on psychological empowerment strategies, especially since these strategies have proven effective in many other therapies and psychological counseling areas. The findings and recommendations of the current study may also open the door to other researchers' efforts to confront future professional anxiety through psychology-based interventions on psychological empowerment to provide more relevant research and studies 


\section{In light of the results of the study, the researchers recommend the following:}

Inviting Al-Balqa Applied University and Jordanian universities in general to adopt diagnostic and treatment programs related to students' future professional anxiety to help them reduce the sense of anxiety in the future career.

Activating academic counseling by enabling the psychologically outstanding students to reduce their stress and anxiety, whether it is related to their current academic life or future career.

Combining a mentorship program based on psychological empowerment with a career counseling program enables outstanding students to define their future career paths.

\section{REFERENCES}

Ahmadi, S., \& Salmi, M. (2015). Career future anxiety and its relationship to irrational thoughts among university student (MSc). Al-Shahid Hama Al-Khader University AlShahid Hama Al-Khader University in El-Oued, Algeria. Retrieved from http://search.shamaa.org/FullRecord?ID=127650

Al Hwayan, O. (2020). Predictive Ability of Future Anxiety in Professional DecisionMaking Skill among a Syrian Refugee Adolescent in Jordan. Occupational Therapy International, 2020, 1-6. http://doi.org/10.1155/2020/4959785

Al-Shannaq, M. M., \& Leppayirta, J. (2020). Comparing Math Anxiety of Scientific Facilities Students as Related to Achievement, and Some Variables. International Journal of Instruction, 13(1), 341-352. https://doi.org/10.29333/iji.2020.13123a

Azizi, S. M., Heidarzadi, E., Soroush, A., Janatolmakan, M., \& Khatony, A. (2020). Investigation the correlation between psychological empowerment and assertiveness in nursing and midwifery students in Iran. Nurse education in practice, 42, 102667. https://doi.org/10.1016/j.nepr.2019.102667

Bin Al-Abyad, A. \& Belmokhtar, R. (2019). University Student and Academic Excellence, Ansana Journal for Research and Studies, Algeria, 10 (2), 298-308. Retrieved 7 May 2021, from https://www.asjp.cerist.dz/en/article/105850

Bisson, K. (2017). The Effect of Anxiety and Depression on College Students' Academic Performance: Exploring Social Support as a Moderator. Digital Commons @ ACU, Electronic Theses and Dissertations. Paper 51. Retrieved from https://digitalcommons.acu.edu/etd/51/

Didouni, Y. \& Bergo, Z. (2020). Psychological empowerment and its impact on job performance. Entrepreneurship Journal of Business Economics, Algeria, 6 (2), 46-59. Retrieved from https://www.asjp.cerist.dz/en/article/108298

Farley, J. (2015). An Examination of High-Achieving College Students: Career Indecision and Career Thoughts (Ph.D). University of Tennessee - Knoxville, USA. Retrieved from https://trace.tennessee.edu/utk_graddiss/3415/ 
Fatiha, D., \& Lamnour, M. (2019). A proposal for a cognitive-behavioural counselling program to reduce stress among students who are excelling in studies. Ansna Journal For Research And Studies, 10(2), 58-72. Retrieved from https://www.asjp.cerist.dz/en/article/105832

Ghanayem, A. (2018). Future professional anxiety and satisfaction with the academic major as predictors of academic achievement among students of the Special Education and Rehabilitation Division. Journal of Special Education, 6(22), 182-230. Retrieved from https://journals.ekb.eg/article_91700.html

Kapanadze, D. (2019). Analyzing Discourses of Gifted Students in Terms of Their Perspectives on Social Gender. International Journal Of Instruction, 12(2), 539-558. http://doi.org/10.29333/iji.2019.12234a

Kong, H., Sun, N., \& Yan, Q. (2016). New generation, psychological empowerment. International Journal Of Contemporary Hospitality Management, 28(11), 2553-2569. http://doi.org/10.1108/ijchm-05-2014-0222

Luoma, J. (2018). Learning ACT Resource Guide, The complete guide to resources for learning Acceptance \& Commitment Therapy. Retrieved 7 May 2021, from https://portlandpsychotherapytraining.com/guide-to-learning-act/

Majali, M. (2019). The effectiveness of a mentorship program in improving the level of self-efficacy of outstanding students in the Sultanate of Oman. Journal Of Al-Madinah International University, 1(30), 387-421. Retrieved from http://ojs.mediu.edu.my/index.php/majmaa/article/view/2396

Majali, S. (2020). Positive Anxiety and Its Role in Motivation and Achievements among University Students. International Journal of Instruction, 13(4), 975-986. http://doi.org/10.29333/iji.2020.13459a

Muhammad, W. (2010). Future anxiety among young people and its relationship to some variables. Journal Of Educational And Psychological Research, 26(27), 331-379. Retrieved from https://www.iasj.net/iasj/article/2693

Mukhaimer, H., \& Al-Wathenani, M. (2018). Vocational Future Anxiety and its Relationship with Academic Self Efficacy and Academic Achievement Motive among umm Al Qura. Reading And Knowledge Journal, 2(201), 15-29. Retrieved from https://search.mandumah.com/Record/899509

Nikpour, A. (2018). Psychological empowerment and organizational innovation: mediating role of job satisfaction and organizational commitment. International Journal Of Organizational Leadership, 7(2), 106-119. http://doi.org/10.33844/ijol.2018.60421

Ozcan, D. (2017). Career decision-making of the gifted and talented. South African Journal Of Education, 37(4), 1-8. http://doi.org/10.15700/saje.v37n4a1521

Peker, M., \& Ulu, M. (2018). The Effect of Pre-Service Mathematics Teachers' Beliefs about Mathematics Teaching-Learning on Their Mathematics Teaching 
Anxiety. International Journal of Instruction, 11(3), 249-264. http://doi.org/10.12973/iji.2018.11318a

Pittig, A., Treanor, M., LeBeau, R., \& Craske, M. (2018). The role of associative fear and avoidance learning in anxiety disorders: Gaps and directions for future research. Neuroscience \& Biobehavioral Reviews, 88, 117-140. http://doi.org/10.1016/j.neubiorev.2018.03.015

Pulliam, N., \& Gonzalez, C. (2018). Success or fraud? Exploring the impacts of the impostor phenomenon among high achieving racial/ethnic minority and first-generation college students. Journal Of Access, Retention \& Inclusion, 1(33), 33-45. Retrieved from

https://www.wcupa.edu/viceProvost/universityCollege/adp/documents/ADP\%20Journal2018-First\%20Edition-corrected.pdf

Sayed, S. (2019). The effectiveness of acceptance and commitment therapy reduces future career anxiety among students of the Special Education Division. Journal Of The Faculty Of Education, Assiut University,35(5), 234-281. Retrieved from https://mfes.journals.ekb.eg/article_103866_543f33f0b6102bcd15ecf7a7862a6c88.pdf

Singh, S. K., \& Singh, A. P. (2019). Interplay of organizational justice, psychological empowerment, organizational citizenship behaviour, and job satisfaction in the context of circular economy. Management Decision. https://doi.org/10.1108/MD-09-2018-0966

Trindade Júnior, S., Sousa, L., \& Carreira, L. (2021). Generalized anxiety disorder and prevalence of suicide risk among medical students. Revista Brasileira De Educação Médica, 45(2), 1-7. https://doi.org/10.1590/1981-5271v45.2-20200043.ING

Twohig, M., \& Levin, M. (2017). Acceptance and Commitment Therapy as a Treatment for Anxiety and Depression: A Review. Psychiatry Journal, 40(1), 751-770. http://doi.org/10.1016/j.psc.2017.08.009

Vignoli, E. (2015). Career indecision and career exploration among older French adolescents: The specific role of general trait anxiety and future school and career anxiety. Journal Of Vocational Behavior, 89(1), $182-191$. http://doi.org/10.1016/j.jvb.2015.06.005

Yousef, S., Athamneh, M., Masuadi, E., Ahmad, H., Loney, T., Moselhy, H. F., ... \& ElBarazi, I. (2017). Association between depression and factors affecting career choice among Jordanian nursing students. Frontiers in public health, 5, 1-8. http://doi.org/10.3389/fpubh.2017.00311

Zimmerman, M. A., Eisman, A. B., Reischl, T. M., Morrel-Samuels, S., Stoddard, S., Miller, A. L., ... \& Rupp, L. (2018). Youth empowerment solutions: Evaluation of an after-school program to engage middle school students in community change. Health Education \& Behavior, 45(1), 20-31. 10.1177/1090198117710491 